\title{
PRAWO DO BYCIA OFFLINE JAKO PODSTAWOWE PRAWO PRACOWNIKA
}

\author{
Abstract \\ The right to disconnect as an employees' fundamental right
}

The ongoing COVID-19 pandemic and the associated possibilities for the employers to order employees to perform their work remotely has caused the widespread perception of the employee's right to be offline outside its working hours (also referred to as a "right to disconnect") as a fundamental right. This article contains a synthetic analysis of the institution of remote working as the main source of threat to employees' rights as well as considerations with regard to proposed solutions aimed at protecting the employee against such threat. On the one hand, remote work has a protective function being instrumental in safeguarding the continuity of businesses and the employee's workplace despite the pandemic, but on the other hand, it significantly interferes with the private sphere and may lead to violations of the regulations on working time. The European Parliament's proposals on the right to be offline should be assessed positively, although they undoubtedly only guarantee an absolute minimum level of protection. The analysis was carried out following the formal dogmatic method also taking into account comparative tools.

Słowa kluczowe: prawo do bycia offline, prawo do odłączenia, praca zdalna

Keywords: right to be offline, right to disconnect, remote work

ASJC: 3308, JEL: K31

\section{Wprowadzenie}

Czas pandemii COVID-19, w szczególności z uwagi na szerokie zastosowanie instytucji pracy zdalnej, spotęgował już występujący w środowisku pracy problem realizacji prawa pracownika do wyłączenia narzędzi cyfrowych do celów zawodowych. Materia ta była analizowana w literaturze polskiej wcześniej (Surdykowska 2019, s. 7), ale dotąd nie doczekała się stosownych inicjatyw legislacyjnych ani szerszej debaty (Eurofound 2020a, s. 18). Regulacje w tym zakresie wprowadzano we Francji (Surdykowska 2019, s. 7), Belgii, Włoszech i Hiszpanii (EPRS 2020, s. 3). Zagadnienie to stało się także przedmiotem zainteresowania na forum europejskim, co zaowocowało rezolucją 
Parlamentu Europejskiego z dnia 21 stycznia 2021 roku zawierającą zalecenia dla Komisji w sprawie prawa do bycia offline (2019/2181(INL)). W akcie tym - dostrzegając pewne zalety cyfryzacji i odpowiedniego wykorzystania narzędzi cyfrowych - wskazuje się, że powstanie kultury pracownika „stale osiągalnego” może się wiązać z negatywnym wpływem na prawa podstawowe pracowników i sprawiedliwe warunki pracy. Prowadzi ona także do zaburzenia równowagi i zacierania granic między życiem prywatnym a zawodowym. Zgodnie z badaniami Eurofoundu 37\% pracowników Unii Europejskiej rozpoczęło w czasie lockdownu pracę z domu, a 27\% osób pracujących w ten sposób potwierdziło pracę w czasie wolnym, aby podołać obciążeniu pracą (Eurofound 2020b). Powyższe dane wskazują, że realizacja omawianego prawa stanowi aktualny problem prawa pracy XXI wieku.

Celem niniejszego artykułu jest analiza zaproponowanej przez Parlament Europejski regulacji, ocena jej potrzeby i klasyfikacja prawa do bycia offline. Jednocześnie - z uwagi na rolę, jaką w procesie rozwoju tej tematyki odegrała praca zdalna - celowe wydaje się spojrzenie w tym zakresie na polską regulację.

\section{Praca zdalna - pojęcie i funkcje}

Praca zdalna jest instytucją nową w polskim prawie pracy. Wprowadzona została ustawą z dnia 2 marca 2020 roku o szczególnych rozwiązaniach związanych z zapobieganiem, przeciwdziałaniem i zwalczaniem COVID-19, innych chorób zakaźnych oraz wywołanych nimi sytuacji kryzysowych (Dz.U. 2020, poz. 1842 tekst jedn., dalej: „ustawa COVID-19") w art. 3, który składał się zaledwie z jednej jednostki redakcyjnej. Regulacja rozbudowana została na mocy ustawy dnia 19 czerwca 2020 roku o dopłatach do oprocentowania kredytów bankowych udzielanych przedsiębiorcom dotkniętym skutkami COVID-19 oraz o uproszczonym postępowaniu o zatwierdzenie układu w związku z wystąpieniem COVID-19 (Dz.U. 2021, poz. 1072 tekst jedn.) w ust. 2-8. Świadczenie pracy z domu - niestanowiące telepracy, a nazywane potocznie home office - było, co prawda, już wcześniej wykorzystywane w praktyce bez wyraźnej podstawy prawnej (Gładoch 2020, s. 9). Jego źródłem było porozumienie pracodawcy i pracownika, i traktowane było jako benefit tego ostatniego (Gładoch 2021).

Zgodnie z aktualną treścią art. 3 ust. 1 ustawy COVID-19:

W okresie obowiązywania stanu zagrożenia epidemicznego albo stanu epidemii, ogłoszonego z powodu COVID-19, oraz w okresie 3 miesięcy po ich odwołaniu, w celu przeciwdziałania COVID-19 pracodawca może polecić pracownikowi wykonywanie, przez czas oznaczony, pracy określonej w umowie o pracę, poza miejscem jej stałego wykonywania (praca zdalna).

Odkodowując treść przywołanej definicji, można stwierdzić, że instytucja pracy zdalnej jest epizodyczna i celowa (Mitrus 2020a, s. 4). Po pierwsze, w sposób jednoznaczny ograniczono czas, w którym można ją stosować. Po drugie, określono cel, jakiemu ma służyć. Jak 
zauważa Leszek Mitrus, praca zdalna jest postrzegana jako metoda zwalczania pandemii (2020a, s 4). Powierzenie pracy zdalnej następuje wyłącznie na polecenie pracodawcy, co oznacza, że jest to akt jednostronny stanowiący przejaw kompetencji kierowniczych pracodawcy, a pracownikowi nie przysługuje roszczenie o jego wydanie (Gładoch 2020, s. 22, 23). Uprawnienie to obejmuje zarówno wydanie polecenia, jak i jego cofnięcie, które jest możliwe w każdym czasie, a zatem także z dnia na dzień. Dariusz Makowski (2020, s. 14) wskazuje jednak, że cofnięcie polecenia nie może naruszać art. $207 \$ 2$ ustawy z dnia 26 czerwca 1974 roku - Kodeks pracy, Dz.U. 2020, poz. 1320 tekst jedn. ze zm., dalej: „Kodeks pracy”, „k.p.”). Ustawa nie przewiduje dla dokonania tych czynności żadnej szczególnej formy, mogą więc nastąpić w dowolny sposób (Gładoch 2020, s. 23). Przesłanki stosowania pracy zdalnej określone zostały w art. 3 ust. 3 ustawy COVID-19. Ustawodawca odwołał się w tym zakresie do następujących warunków: umiejętności, możliwości technicznych oraz lokalowych, a także rodzaju pracy umożliwiającej jej wykonywanie w tej formie. Przepis nie przewiduje możliwości odmowy pracownika, nie znajduje tu zastosowania także regulacja art. 42 k.p. Jeżeli pracownik sprzeciwi się poleceniu pracodawcy w sposób nieuzasadniony (problematyczna jest jednak kwestia oceny oświadczenia pracownika; Gładoch 2020, s. 29), to mając na względzie cel tej regulacji, pracodawca będzie uprawniony do złożenia mu oświadczenia o rozwiązaniu umowy o pracę za wypowiedzeniem, a w skrajnych wypadkach nawet bez wypowiedzenia (art. 52 \$ 1 k.p.) (Baran, Książek 2020, s. 52; Mitrus 2020a, s. 4; Zagrobelny 2020, s. 5; za ostrożnością w stosowaniu tego trybu: Gładoch 2020, s. 29). Skierowanie do wykonywania pracy zdalnej jest możliwe tylko na określony czas. Wobec tego Dariusz Makowski (2020, s. 11) słusznie zauważa, że w aspekcie temporalnym przedmiotowa regulacja jest podwójnie ograniczona. Jeżeli po upływie określonego czasu nadal będzie występowała potrzeba wykonywania pracy w tej formie, regulacja ta (wnioskując a maiori ad minus) umożliwia pracodawcy wydanie ponownego polecenia.

W początkowej fazie obowiązywania tego unormowania sformułowanie, że praca ma być wykonywana poza stałym miejscem, należało interpretować w ten sposób, że pracownik miał ją świadczyć gdzie indziej, co nie oznaczało, że miał ją świadczyć w domu (Pisarczyk, Boguska 2020). Odwołanie się w ust. 3 do możliwości lokalowych pracownika wydaje się jednak zawężać terytorialnie obszar świadczenia pracy (Mitrus 2020a, s. 6), choć nadal określenie to nie jest w pełni jednoznaczne.

Podmiotowy zakres zastosowania omawianej regulacji obejmuje nie tylko pracowników zatrudnionych na podstawie stosunku pracy (art. 2 k.p.), ale także - na mocy art. 3 ust. 2 ustawy COVID-19 - funkcjonariuszy służb mundurowych wymienionych $\mathrm{w}$ tym przepisie.

Nie tracąc z pola widzenia przedmiotu niniejszego artykułu, należy zaznaczyć, że zgodnie $z$ art. 3 ust. 3 ustawy COVID-19 praca w tej formie świadczona jest w szczególności za pomocą środków bezpośredniego porozumiewania się na odległość, choć trzeba pamiętać, że może także dotyczyć wykonywania części wytwórczych lub usług materialnych. Dariusz Makowski (2020, s. 11) zauważa problematyczność pojęcia pracy zdalnej w kontekście przypisywanego mu potocznie znaczenia i zakresu 
przedmiotowego regulacji. Leszek Mitrus (2020a, s. 4) wskazuje, że w języku prawniczym można posługiwać się pojęciem „pracy na odległość”. Zakres przedmiotowy nie jest ograniczony do pracy z wykorzystaniem nowoczesnych technologii, choć dla dalszych wywodów znaczenie będzie miała jednak jedynie taka praca zdalna, którą wykonuje się za pomocą środków bezpośredniego porozumiewania się na odległość. Jednocześnie zgodnie z ust. 6 i 7 art. 3 ustawy COVID-19 na polecenie pracodawcy pracownik ma obowiązek prowadzić ewidencję wykonywanych czynności obejmującą ich opis, datę i czas wykonania. W poleceniu określa się formę, w jakiej ma być przygotowywana ewidencja i częstotliwość jej sporządzania.

Kończąc rozważania w przedmiocie pracy zdalnej, trudno nie poświęcić kilku uwag funkcji spełnianej przez tę instytucję. Jak wspomniano powyżej, już wcześniej znane było zarówno okazjonalne świadczenie pracy $\mathrm{z}$ domu przez pracowników $\mathrm{w}$ formie tak zwanego home office, jak i stałe w formie telepracy unormowanej w Kodeksie pracy (która to forma pracy nie spełniła jednakże pokładanych w niej oczekiwań, głównie z uwagi na nadmiernie szczegółową regulację; Mitrus 2020b, s. 8). Praca zdalna różni się jednak od nich tym, że wprowadzona została jako niezwłoczna odpowiedź na występujące zjawisko, co zresztą nie pozostało bez wpływu na jakość unormowania, w szczególności w początkowej fazie jego istnienia. Nie powinno być jednak kontrowersyjne stwierdzenie, że była ona potrzebna i stanowiła dobrą odpowiedź na zaistniałe potrzeby. $Z$ jednej strony bowiem pozwoliła na dalsze funkcjonowanie niektórych zakładów pracy bez ryzyka wystąpienia przestoju, mimo wystąpienia licznych zachorowań wśród pracowników. To z kolei miało wpływ na ich kondycję finansową i pozwoliło na utrzymanie zatrudnienia. $Z$ drugiej strony wiązało się z brakiem narażenia pracowników na zachorowanie, a także możliwością zachowania miejsc pracy z uwagi na niepogorszenie sytuacji pracodawcy wywołanej licznymi absencjami pracowników. Oba te aspekty działania omawianej regulacji są ze sobą sprzężone. W tym wymiarze zrealizowana została funkcja ochronna prawa pracy. Daniel Książek (2020, s.109) zauważa jednak, że jednocześnie regulacja ta przełamuje wspomnianą funkcję, realizowaną przez ochronę pewności warunków pracy, między innymi miejsca pracy. Zgodzić się trzeba z przywołanym stanowiskiem, przy czym nie oznacza to, że regulacja ta nie może realizować funkcji ochronnej in genere. Należy pamiętać o jej nadrzędnym i długoterminowym celu, jakim jest łagodzenie negatywnych skutków pandemii w sferze zatrudnienia, który to cel uzasadnia wyjątkowość omawianej regulacji. Ukształtowane w art. 3 ustawy COVID-19 uprawnienie pracodawcy realizuje ponadto funkcję organizatorską w tym sensie, że wzmacnia jego uprawnienia kierownicze i umożliwia mu sprawne przekształcenie procesu pracy. W konsekwencji należy stwierdzić multifunkcyjność omawianej regulacji.

1 Regulacja dotycząca pracy na odległość była przewidziana w projekcie Kodeksu pracy z 2018 roku w dziale VII obejmującym art. 165-168. Dotyczyła pracy okazjonalnej, wykonywanej nie częściej niż przeciętnie jeden dzień w tygodniu, poza stałym miejscem pracy z wykorzystaniem urządzeń elektronicznych (Gładoch 2020, s. 17). Projektowana i istniejąca regulacja różnią się jednak istotnie. 


\section{Ryzyko związane z wykonywaniem pracy z wykorzystaniem narzędzi cyfrowych}

W czasie pandemii COVID-19 istotną zmianą w funkcjonowaniu społeczeństwa było nie tylko częste korzystanie z pracy zdalnej, ale także wprowadzenie tak zwanego lockdownu, który związany był między innymi z zamknięciem szkół i wprowadzeniem zdalnego nauczania. Nie jest tajemnicą, że w istotnym zakresie to na rodzicach spoczywał obowiązek pomocy i nadzorowania dzieci w tym czasie. Wielu z nich nie chciało jednocześnie rezygnować z pracy i w sytuacji skierowania do pracy zdalnej godzili się na łączenie obowiązków. Świadczenie pracy w takich warunkach niejednokrotnie skutkowało jednak (i w miarę możliwości) koniecznością jej przerywania w ciągu dnia i powrotem do niej w dogodnym dla pracownika momencie. To z kolei powodowało skrócenie czasu pracy, który „nadrabiany” był wieczorem lub w nocy. Pracodawcy stawali także przed pokusą nierespektowania godzin pracy pracowników, którzy $\mathrm{z}$ ich perspektywy - pracując zdalnie w domu, cały czas byli w pracy. Związane ze zmianą sposobu życia wdrożenie zasady social distancing skutkowało „byciem ciągle na telefon", a brak konieczności wyjścia z pracy i udania się do domu prowadził do zacierania się godziny, w której pracownicy standardowo kończyli pracę. Skierowanie pracownika do pracy w trybie zdalnym nie powoduje jednak automatycznie żadnej zmiany w obowiązującym go systemie czasu pracy i nadal obowiązuje go norma czasu pracy uregulowana w art. 129 k.p. (Gładoch 2020, s. 33). Postuluje się wprowadzenie dla takich pracowników zadaniowego czasu pracy, choć nie zawsze jest to możliwe (Rycak 2020, s. 311), lub ruchomego albo indywidualnego rozkładu czasu pracy (Gładoch 2020, s. 39). Praca z domu wiąże się z częściowym przeniesieniem ryzyka organizacyjnego na pracownika, w szczególności w postaci wydłużenia czasu pracy (Gładoch 2020, s. 45). Regulacja ustawy COVID-19 przerzuca także na niego obowiązek ewidencjonowania czasu pracy, a ściślej - dopilnowania, aby zachowane były normy czasu pracy. De facto pracodawca o pracy w wymiarze ponadnormatywnym może więc być poinformowany dopiero po otrzymaniu zestawienia sporządzonego przez pracownika.

Warto jednak zauważyć, że choć - jak wspomniano na początku niniejszego artykułu - pandemia i wywołana nią potrzeba skierowania pracowników do pracy zdalnej wzmogły potrzebę uregulowania omawianej kwestii, to była ona już dostrzegana w sferze stosunków pracy przy negocjacjach europejskich partnerów społecznych dotyczących cyfryzacji, a Parlament Europejski w planie pracy na 2019 rok wskazał na zamiar przygotowania swojej propozycji regulacji tej kwestii. Oznacza to, że problematyka bycia offline nie może być wiązana jedynie z pracą zdalną, a prawo do odłączenia od sieci musi być prawem powszechnym, przysługującym wszystkim pracownikom niezależnie od tego, czy świadczą pracę z domu. Obserwuje się, że pracownicy wysoce mobilni, wykorzystujący do realizacji zadań ICT (ang. information and communication technologies, technologie informacyjno-komunikacyjne) są szczególnie narażeni na przekraczanie norm czasu pracy (Eurofound 2020a, s. 6). Przyczynia się do tego używanie w pracy różnych technologii (Secunda 2019, s. 2). 
W rezolucji Parlamentu Europejskiego wskazano, że cyfryzacja, poza niewątpliwymi zaletami, niesie ze sobą również ryzyko intensyfikacji pracy i wydłużenia jej czasu, co prowadzi do zatarcia granic między życiem zawodowym a prywatnym. Może to wpływać na fizyczne i psychiczne bezpieczeństwo i higienę pracy. Wskazano także na związane $\mathrm{z}$ długotrwałym korzystaniem $\mathrm{z}$ narzędzi cyfrowych obniżenie koncentracji oraz przeciążenie kognitywne i emocjonalne, a także możliwe napięcia i zaburzenia mięśniowo-szkieletowe oraz uzależnienie od technologii, zaburzenia snu, wyczerpanie emocjonalne, niepokój, wypalenie zawodowe. Paul Secunda zauważa, że coraz częściej można mówić, że miejsce pracy jest, tam gdzie zostanie zabrany stosowny sprzęt (smartfon, laptop) i gdzie można kontynuować pracę, która jest wykonywana po pracy już nie tylko w domu, ale też w czasie podróży czy na wakacjach. Możliwość odłączenia jest konieczna do odzyskania przez pracowników work-life balance, zatraconego przez nieustannie pozostawanie w zasięgu. Taki, coraz częstszy, styl życia wpływa na ich zdrowie i bezpieczeństwo (Secunda 2019, s. 8).

Postęp technologiczny i świadczenie pracy za pomocą urządzeń cyfrowych niejako wymusza zwiększenie czasu pracy i bycie w ciągłej gotowości. Jak wskazano w ocenie przeprowadzonej przez Biuro Analiz Parlamentu Europejskiego, „bycie dostępnym” wiąże się z wyższą produktywnością i uważa się za konieczne dla rozwoju kariery zawodowej (EPRS 2020, s. 1). W porozumieniu ramowym europejskich partnerów społecznych z 22 czerwca 2020 roku dotyczącym cyfryzacji (BusinessEurope, SMEunited, CEEP, ETUC 2020) zauważono, że proces transformacji cyfrowej wiąże się z korzyściami dla pracodawców, pracowników i osób szukających pracy między innymi przez zwiększenie nowych możliwości zatrudnienia i nowych sposobów organizacji pracy. Dostrzeżono równocześnie wiążące się z nim ryzyko obejmujące także organizację pracy i warunki pracy oraz równowagę między życiem zawodowym a prywatnym. Z żalem należy odnotować, że w porozumieniu nie odniesiono się wprost do kwestii prawa do bycia offline. Postuluje się jednak wprowadzenie działań prewencyjnych w związku z możliwością niewłaściwego wykorzystywania elastycznej organizacji czasu pracy. Wskazano, że pracodawca jest obowiązany dbać o bezpieczeństwo i zdrowie pracowników. Zaproponowano, aby wdrożyć środki mające na celu przeciwdziałanie takim zjawiskom obejmujące między innymi udzielanie informacji, w tym na temat korzystania z narzędzi cyfrowych, na przykład poczty elektronicznej, oraz zmierzające do zaangażowania kierownictwa w tworzenie kultury pozwalającej uniknąć kontaktu poza godzinami pracy. Wskazano, że osiągnięcie celów organizacyjnych nie powinno wymagać połączenia poza godzinami pracy, a pracownik nie ma obowiązku być dostępny. Jednocześnie powiązano pracę $\mathrm{w}$ dodatkowym czasie z koniecznością odpowiedniej rekompensaty. Zaproponowano wprowadzenie procedur ostrzegania i wspierania wobec pracowników, z którymi pracodawca nie może się skontaktować po godzinach. Wspomniany akt odwołuje się implicite do omawianego prawa, nakazując jego pełne poszanowanie. 


\section{Prawo do bycia offline - definicja}

Jak zostało wspomniane, omawiana problematyka objęta została rezolucją Parlamentu Europejskiego. Wskazać należy, że Parlament Europejski samodzielnie nie ma uprawnień prawodawczych (Górka 2017, s. 152), a wyłączne prawo inicjatywy legislacyjnej w tym obszarze przysługuje Komisji Europejskiej, zgodnie z art. 17 Traktatu o Unii Europejskiej, (Dz.Urz. UE C 2012, nr 326/13, dalej: „TUE”) oraz art. 289 i 294 Traktatu o funkcjonowaniu Unii Europejskiej (Dz.Urz. UE C 2012, nr 326/47, dalej: „TfUE”) (Barcz 2017, s. 279). Traktat przyznaje jednak Parlamentowi Europejskiemu prawo do żądania od Komisji Europejskiej przedstawienia propozycji dotyczących spraw wymagających, jego zdaniem, wydania aktu unijnego (art. 225 TfUE), co określa się mianem pośredniej inicjatywy legislacyjnej (Górka 2017, s. 153; Grzeszczak 2012, s. 101). Dlatego też w rezolucji wezwano Komisję Europejską, by dokonała oceny ryzyka związanego z brakiem ochrony do bycia offline i zajęła się tym problemem. Rezolucja ma więc charakter niewiążący i jest wstępnym etapem, impulsem do procesu prawotwórczego dotyczącego danej problematyki. Załącznik do rezolucji zawierający projekt regulacji nie stanowi zatem oficjalnego projektu dyrektywy, a jest jedynie propozycją PE, która nie musi zostać uwzględniona przez Komisję w tym kształcie. W przypadku, gdyby Komisja zajęła się omawianym zagadnieniem, wdrożenie regulacji nastąpiłoby w drodze dyrektywy (art. 153 TfUE). Dyrektywa jako akt pochodnego prawa unijnego skierowany jest do państw członkowskich i wiąże je co do celu (rezultatu), jaki mają osiągnąć, pozostawiając swobodę w zakresie metody i formy (Kurcz 2004, s. 31 i n.; Kurcz 2012, s. 651 i n.; Bradley 2017, s. 100; Wyrozumska 2017, s. 250). Zasadniczo dyrektywy stanowią swoiste prawo ramowe, choć występują także takie o charakterze maksymalnym, niezostawiające państwom członkowskim zbyt wiele swobody (Kurcz 2004, s. 31 i n.; Bradley 2017, s. 100; Wyrozumska 2017, s. 251).

Przechodząc do analizy zaproponowanych rozwiązań, należy wskazać, iż w dokumencie roboczym Eurofound The Right to Disconnect in the 27 EU Member States (2020a, s. 1) wskazano, że prawo do bycia offline może być rozumiane dwojako: jako uprawnienie pracownika do powstrzymania się od pracy poza czasem pracy za pośrednictwem narzędzi cyfrowych, albo jako obowiązek pracodawcy zapewnienia, że pracownicy nie będą pracować w czasie odpoczynku i urlopu (prawo do bycia odłączonym). Zaproponowana w projekcie Parlamentu Europejskiego definicja „bycia offline” jest następująca: nieangażowanie się poza czasem pracy w zadania związane z pracą i nieuczestniczenie w komunikacji za pomocą narzędzi cyfrowych, bezpośrednio lub pośrednio. Przyjęto zatem pierwszą z możliwych koncepcji. Pojęcie czasu pracy rozumieć należy zgodnie z dyrektywą 2003/88/WE Parlamentu Europejskiego i Rady z dnia 4 listopada 2003 roku dotyczącą niektórych aspektów organizacji czasu pracy (Dz.Urz. UE L 2003, nr 299/9). W akcie tym czas pracy oznacza każdy okres, podczas którego pracownik pracuje, jest do dyspozycji pracodawcy oraz wykonuje swoje działania lub spełnia obowiązki, zgodnie z przepisami krajowymi lub praktyką krajową. 
Analizując przedstawione określenie należy stwierdzić, że projektodawca chciał ująć je możliwie szeroko. Zakreślił on dwa obszary sposobu wykonywania obowiązków pracowniczych: związany z komunikacją i niedotyczący jej. Językowa wykładnia polskiej wersji tego przepisu może pozostawiać wątpliwości co do dwóch kwestii. Po pierwsze, czy na pewno mamy do czynienia $\mathrm{z}$ dwoma formami wykonywania zadań. Skoro projektodawca posłużył się koniunkcją może chodziło tu o nieangażowanie się w zadania przez komunikację. W wypadku odpowiedzi negatywnej: czy oba obszary są realizowane za pomocą narzędzi cyfrowych? W pierwszej kwestii - analizując dokumenty robocze, w tym przywoływaną już ocenę Biura Analiz Parlamentu Europejskiego, w której stwierdzono: „There is currently no existing or proposed EU legislation that directly addresses the scope or timing of work-related electronic communication between employers and employees" ${ }^{\prime 2}$ - wydawałoby się, że zasadnicze w omawianym prawie jest właśnie pozostawanie poza komunikacją; podobnie analizując dokument roboczy Eurofound (2020a, passim). Jednakże wykładnia przeprowadzona na podstawie wersji angielskiej i niemieckiej pozwala stwierdzić, że chodzi tu o wspomniane dwa obszary, gdyż posłużono się tam alternatywami or i oder ${ }^{3}$. Wykładając art. 2 pkt. 1 projektu Parlamentu Europejskiego systemowo w związku $\mathrm{z}$ art. 1 ust. 1, a więc konfrontując definicję bycia offline z określeniem przedmiotu projektowanej dyrektywy, można z kolei stwierdzić, że w obu formach chodzi o posłużenie się narzędziem cyfrowym. Taki jest zresztą sens omawianej regulacji. Explicite wynika to z niemieckiej wersji językowej projektu, gdzie posłużono się sfomułowaniem :„,(...) dass außerhalb der Arbeitszeit weder direkt noch indirekt mittels digitaler Werkzeuge arbeitsbezogene Tätigkeiten ausgeübt werden oder arbeitsbezogene Kommunikation erfolgt"4 umieszczając pojęcie narzędzi cyfrowych przed sposobami świadczenia pracy.

Dalej zauważyć trzeba, że projekt Parlamentu Europejskiego posługuje się właśnie pojęciem narzędzi cyfrowych. Zasadniczo polski ustawodawca w analogicznych sytuacjach używa sformułowania „środki komunikacji elektronicznej”s lub jak w ustawie COVID-19 - „środki bezpośredniego porozumiewania się na odległość”. Artykuł 1 ust. 1

2 Tłum.: „Aktualnie nie ma żadnego istniejącego ani proponowanego prawodawstwa UE, które bezpośrednio odnosiłoby się do zakresu lub czasu komunikacji elektronicznej związanej z pracą między pracodawcami a pracownikami".

${ }^{3} \mathrm{~W}$ wersji angielskiej: "disconnect" means not to engage in work-related activities or communications by means of digital tools, directly or indirectly, outside working time. W wersji niemieckiej: „Nichterreichbarkeit“, dass außerhalb der Arbeitszeit weder direkt noch indirekt mittels digitaler Werkzeuge arbeitsbezogene Tätigkeiten ausgeübt werden oder arbeitsbezogene Kommunikation erfolgt.

4 Tłum.: „(...) poza czasem pracy nie będzie wykonywana ani bezpośrednio ani pośrednio za pośrednictwem narzędzi elektronicznych żadna czynność związana z pracą, ani nie będzie następowała komunikacja związana z pracą".

5 Zgodnie z art. 2 pkt 5 ustawy z dnia 18 lipca 2002 roku o świadczeniu usług drogą elektroniczną (Dz.U. 2020, poz. 344 tekst jedn.) są to rozwiązania techniczne, w tym urządzenia teleinformatyczne i współpracujące z nimi narzędzia programowe, umożliwiające indywidualne porozumiewanie się na odległość przy wykorzystaniu transmisji danych między systemami teleinformatycznymi, a w szczególności poczta elektroniczna. 
projektu Parlamentu Europejskiego, określający przedmiot i zakres regulacji, wskazuje, że narzędzia cyfrowe to w szczególności narzędzia ICT. Pojęcie to obejmuje technologię przetwarzającą, gromadzącą i przesyłającą informacje w formie elektronicznej (GUS 2016, s. 14). Wskazuje się, że obejmuje nie tylko same programy, ale również sprzęt komputerowy oraz peryferyjny (Wojnicka-Sycz 2013, s. 403), co oznaczałoby, że jest to pojęcie szersze niż dwa wcześniej przytoczone. Pracą z wykorzystaniem narzędzia cyfrowego będzie także praca na komputerze lub innych urządzeniach niezwiązana $\mathrm{z}$ komunikowaniem się. Takie rozumienie pojęcia narzędzi cyfrowych w pełni odpowiada definicji odwołującej się do wskazanych dwóch obszarów realizacji obowiązków pracowniczych. W wymiarze lingwistycznym można jednak dostrzec pewną dysharmonię, polegającą na tym, że sformułowanie offline oznacza przecież bycie poza zasięgiem sieci Internet, zatem pojęcie to nie powinno w ogóle dotyczyć takich sytuacji. Jednakże zgodnie z przytoczoną propozycją definicji bycie offline obejmuje też nieangażowanie się $\mathrm{w}$ realizację zadań, które $\mathrm{w}$ danym momencie nie wiążą się z wykorzystaniem do pracy połączenia z siecią. Ponadto trzeba pamiętać, że dalszy element definicji odwołuje się do bezpośredniości i pośredniości form realizacji obowiązków pracowniczych. O ile jasne jest, że w przypadku komunikacji chodzi tu o czynne i bierne jej śledzenie, a więc odpisywanie na wiadomości, jak i ich czytanie, o tyle mogą powstać trudności wykładnicze w odniesieniu do tego, jak rozumieć pośrednie angażowanie się w zadania związane z pracą. Trzeba stwierdzić, że może tu chodzić o przygotowywanie zaplecza do realizacji określonych zadań, w tym właśnie przywołane wykorzystanie narzędzi cyfrowych bez dostępu do sieci.

Analizując wprowadzoną do polskiego systemu prawa instytucję pracy zdalnej i konfrontując ją z projektowaną regulacją prawa do bycia offline, należy zauważyć, iż ich zakresy pokrywają się tylko częściowo. Wynika to z szerszej płaszczyzny przedmiotowej art. 3 ustawy COVID-19. Prawo do bycia offline będzie dotyczyć tylko tych pracowników, którzy świadczą pracę z wykorzystaniem środków bezpośredniego porozumiewania się na odległość.

\section{Klasyfikacja prawa do bycia offline}

W rezolucji Parlamentu Europejskiego wskazuje się, że „prawo do bycia offline jest prawem podstawowym nierozerwalnie związanym z nowymi wzorcami pracy w nowej erze cyfrowej”. Podkreśla się także, że jest ono istotne dla ochrony zdrowia pracowników i ich samopoczucia zarówno fizycznego, jak i psychicznego. Odnotowuje się bowiem, że pracownicy wykonujący pracę z domu są częściej narażeni na stres, lęk, depresję i wypalenie zawodowe. Jednocześnie zauważa się, że nie istnieje żadne szczegółowe prawo Unii Europejskiej dotyczące prawa pracownika do wyłączenia narzędzi cyfrowych. Z omawianego aktu wynika jednoznacznie, że wyodrębnienie tego prawa jest reakcją na zmiany zachodzące w stosunkach pracy związane $\mathrm{z}$ wykorzystaniem narzędzi cyfrowych do celów zawodowych i wielokrotnie podkreśla się konieczność respektowania czasu 
pracy i odpoczynku pracownika oraz kwestię jego bezpieczeństwa i zdrowia. Projekt Parlamentu Europejskiego odwołuje się w preambule do art. 31 Karty praw podstawowych Unii Europejskiej (Dz.Urz. UE C 2012, nr 326/02, dalej: „KPP”), zgodnie z którym każdy pracownik ma prawo do warunków pracy szanujących jego zdrowie, bezpieczeństwo i godność (ust. 1) oraz każdy pracownik ma prawo do ograniczenia maksymalnego wymiaru czasu pracy, do okresów dziennego i tygodniowego odpoczynku oraz do corocznego płatnego urlopu (ust. 2). Problematyka praw podstawowych stała się przedmiotem zainteresowania Unii Europejskiej pod koniec lat 60. Trybunał Sprawiedliwości odwołał się do tego pojęcia w miejsce powszechnie stosowanego określenia „prawa człowieka”, choć merytorycznie nie występują między nimi różnice (Florczak 2009, s. 14). W prawie wspólnotowym częściej można jednak spotkać się z pierwszym z nich. Źródła ochrony praw podstawowych w systemie prawa Unii Europejskiej wynikają ze wspólnych tradycji konstytucyjnych państw członkowskich (Florczak 2009, s. 14; Wyrozumska 2017, s. 342). Uznawane są one za część zasad ogólnych prawa Unii Europejskiej i określa się je mianem fundamentu Unii Europejskiej (Kornobis-Romanowska 2016, s. 15; Wyrozumska 2017, s. 343). Karta praw podstawowych zawiera katalog owych praw, przy czym nie mają one jednolitego charakteru. Dzieli się je bowiem na prawa i zasady (Wyrozumska 2017, s. 354). Artykuł $31 \mathrm{KPP}$ w całości uznawany jest za przyznający prawa pracownikom, choć występowały wątpliwości co do charakteru ust. 2 tego przepisu (Mitrus 2013, s. 24). Trybunał Sprawiedliwości Unii Europejskiej potwierdził jednak jego bezpośrednie stosowanie (wyrok Trybunału Sprawiedliwości Unii Europejskiej z dnia 6 listopada 2018 roku w sprawie Stadt Wuppertal przeciwko Marii Elisabeth Bauer oraz Volker Willmeroth, jako właściciel spółki TWI Technische Wartung und Instandsetzung Volker Willmeroth eK przeciwko Martinie Broßonn, C-569/16 i C-570/16, ECLI:EU:C:2018:871; wyrok Trybunału Sprawiedliwości Unii Europejskiej z dnia 6 listopada 2018 roku w sprawie Max-Planck-Gesellschaft zur Förderung der Wissenschaften eV przeciwko Tetsujiemu Shimizu, C-684/16, ECLI:EU:C:2018:874; Surdykowska 2020, s. 12 i n.) $)^{6}$. W literaturze wskazuje się, że gwarancje zawarte $\mathrm{w}$ tym przepisie wykraczają poza sformułowanie ogólnych wytycznych programowych, a wynikające z nich prawa mają fundamentalne znaczenie (Mitrus 2020c, nr brzegowy 4). Zapewnienie odpowiednich oraz bezpiecznych warunków zatrudnienia jest jednym z głównych założeń prawa pracy i prawo to leży u podstaw wszelkich innych praw pracowniczych (Mitrus 2020c, nr brzegowy 4; Kiełbasa 2017, II § 3). Jednocześnie zauważa się, że prawo to ujęte w ust. 2 jest podkategorią, uszczegółowieniem prawa zawartego w ust. 1 (Jarass 2021, nr brzegowy 9; Hüpers, Reese 2019, nr brzegowy 26). Pojęcie „warunki pracy” odnosi się bowiem także do ukształtowania przebiegu procesu pracy (Jarass 2021, nr brzegowy 7).

6 W kontekście prawa polskiego pamiętać oczywiście należy o protokole nr 30 z 30 marca 2010 roku w sprawie stosowania Karty praw podstawowych Unii Europejskiej do Polski i Zjednoczonego Królestwa (Dz.Urz. UE C 2010, nr 83/313), zgodnie z którym nic, co zawarte jest w tytule IV, nie tworzy praw, które mogą być dochodzone na drodze sądowej, z wyjątkiem przypadków, gdy Polska lub Zjednoczone Królestwo przewidziały takie prawa w swoim prawie krajowym. 
W projekcie Parlamentu Europejskiego odwołano się także do analogicznych regulacji występujących w Europejskim filarze praw socjalnych, konwencji i zaleceń Międzynarodowej Organizacji Pracy oraz praw uwzględnionych w Zrewidowanej Europejskiej karcie społecznej Rady Europy. Wreszcie powołano się na art. 24 Powszechnej deklaracji praw człowieka, na mocy którego każdy człowiek ma prawo do urlopu i wypoczynku, włączając w to rozsądne ograniczenie godzin pracy i okresowe płatne urlopy. Wielość aktów prawnych odnoszących się do omawianych praw w sposób jednoznaczny potwierdza ich pierwszorzędne znaczenie.

Odnosząc powyższe do polskiego prawa, należy zauważyć, iż zgodnie z art. 66 Konstytucji Rzeczypospolitej Polskiej z dnia 2 kwietnia 1997 roku (Dz.U. 1997, nr 78, poz. 483 z dnia 16 lipca 1997 roku, dalej: „Konstytucja RP”) „Każdy ma prawo do bezpiecznych i higienicznych warunków pracy, a pracownik ma prawo do określonych w ustawie dni wolnych od pracy i corocznych płatnych urlopów; maksymalne normy czasu pracy określa ustawa”. Prawa te należą do praw drugiej generacji jako prawa socjalne. Należą one do praw podstawowych, które stanowią kategorię nadrzędną (Kiełbasa 2017, II $\$ 3)$. Prawa socjalne, jak zauważa Marcin Kiełbasa (2017, II $₫ 3$ ), obejmują otwarty, ciągle ewoluujący katalog, zgodnie ze zmianami następującymi w społeczeństwie.

Skorelowane z powyższymi prawami podstawowe zasady prawa pracy uregulowane zostały odpowiednio w art. 14 i 15 k.p. Zbigniew Góral (2017, s. 1112) zauważa, że ustanowiony w Kodeksie pracy katalog zasad prawa pracy odzwierciedla fundamentalne prawa pracownicze, jakim daje się wyraz w normach prawa międzynarodowego i europejskiego. Zgodnie z pierwszą z wymienionych zasad, pracownik ma prawo do wypoczynku, który zapewniają przepisy o czasie pracy, dniach wolnych od pracy oraz urlopach wypoczynkowych. Kodeks określa zasadniczą maksymalną dobową normę czasu pracy oraz dopuszczalną liczbę nadgodzin. Reguluje kwestie dobowego i tygodniowego wypoczynku, a czas ten powinien być nieprzerwany (Góral 2017, s. 1114). Artykuł $152 \$ 2$ k.p. statuuje zakaz zrzeczenia się prawa do urlopu, co oznacza, że prawo to ma charakter osobisty i niezbywalny oraz że urlop powinien być udzielany w naturze (Góral 2017, s. 1116). Ustawodawca wprost określa dopuszczalne przypadki przerwania pracownikowi urlopu (odwołania), które jako naruszające jego fundamentalne prawo wykładać należy ściśle. Druga z zasad wiąże się bezpośrednio z obowiązkiem pracodawcy ochrony życia i zdrowia pracownika, zarówno psychicznego, jak i fizycznego (Góral 2017, s. 1124). Między czasem pracy a bezpiecznymi i higienicznymi warunkami pracy istnieje związek polegający na tym, że te ostatnie wiążą się z redukowaniem czynników negatywnie wpływających na organizm, a czas pracy może być za taki czynnik uznany (Krzywoń 2017, s. 417).

Czy wobec tego, co zostało już powiedziane - w świetle omówionego ryzyka i definicji prawa do bycia offline, i konfrontując je z przywołanymi prawami do odpoczynku oraz bezpiecznych i higienicznych warunków pracy - jest miejsce na wyodrębnienie prawa do bycia offline, czy też istniejące prawa są w tym zakresie wystarczające? Na tak postawione

7 Choć pierwsze z nich jest też w literaturze kwalifikowane jako prawo pierwszej generacji z uwagi na to, że przedmiotem ochrony jest życie i zdrowie (Sobczyk, Buch 2016, nr brzegowy 9). 
pytanie odpowiedzieć należy, że w aktualnym stanie prawnym, w którym prawo to nie jest uregulowane, a występują uniwersalne normy dotyczące zarówno prawa do wypoczynku, jak i związane z bezpiecznymi i higienicznymi warunkami pracy, zauważyć można brak uprawnienia pracownika celowanego we wspomniane zagrożenia, które są coraz bardziej aktualne i narastające. Istnienie wspominanych regulacji nie przeszkodziło bowiem powstaniu omówionego w niniejszym artykule ryzyka, co oznacza, że w tym aspekcie są one niewystarczające.

Prawo do bycia offline $\mathrm{z}$ uwagi na zakotwiczenie w Karcie praw podstawowych należy zakwalifikować jako prawo podstawowe. $Z$ uwagi na jego przynależność do prawa pracy stanowić ono będzie jedno z podstawowych praw pracownika. Kwestia swoistej wtórności omawianego prawa nie może prowadzić do stwierdzenia, że jego uregulowanie stanowić będzie superfluum. Pomimo bowiem niesamodzielności, jego wyodrębnienie jest konieczne z uwagi na nowe zagrożenia wynikające z rozwoju pracy za pośrednictwem narzędzi cyfrowych. Jednocześnie należy stwierdzić, że stanowi ono iunctim między problematyką prawa do wypoczynku oraz bezpiecznych i higienicznych warunków pracy. Wartością dodaną w stosunku do wskazanych praw jest wyraźne odwołanie się do wykorzystania narzędzi cyfrowych. Proponowana regulacja stanowi odpowiedź na związane z nimi zagrożenia i kreowaną kulturę pracownika ciągle dostępnego.

\section{Realizacja prawa do bycia offline}

Problematyka prawa od bycia offline nie jest uregulowana w prawie polskim. Aktualnie nie planuje się także jej wprowadzenia (zob. przedostatni podrozdział artykułu). Wskazane powyżej przepisy Konstytucji RP i Kodeksu pracy implicite zawierają związki $\mathrm{z}$ omawianym zagadnieniem, lecz wydaje się to niewystarczające. Rozwiązania w tym zakresie jednak już występują w niektórych krajach europejskich. Przykładowo we Francji i Belgii regulacja ta obejmuje pracodawców zatrudniających powyżej pięćdziesięciu pracowników (Eurofound 2020a, s. 41 i n.). W Niemczech, pomimo braku stosownych aktów prawnych, ale z uwagi na wyjątkowo rozwinięty system negocjacji zbiorowych, wiele firm wdrożyło rozwiązania w tym zakresie (EPRS 2020, s. 4). W ustawodawstwie hiszpańskim prawo to zostało uregulowane wprost i nałożono na pracodawców obowiązek ustanowienia polityk gwarantujących jego realizację (Eurofound 2020a, s. 42). Regulacja włoska dotyczy tak zwanych smart-workers, łączących pracę z biura z pracą zdalną, i wymaga indywidualnych uzgodnień w zakresie prawa do bycia offline, choć możliwe są również układy zbiorowe w tej kwestii (Eurofound 2020a, s. 43).

Wprowadzenie regulacji na poziomie europejskim może przyczynić się do zagwarantowania lepszej ochrony pracownikom i jest zgodne z zasadą pomocniczości (Wyrozumska 2017, s. 110). Projekt Parlamentu Europejskiego w art. 3 nakłada na państwa członkowskie obowiązek dopilnowania, by pracodawcy podjęli niezbędne działania w celu zagwarantowania pracownikom możliwości korzystania z prawa do bycia offline i wprowadzili obiektywne, niezawodne i dostępne systemy umożliwiające 
pomiar czasu pracy. Realizacja tego zadania może polegać na konieczności powiązania pracy za pomocą narzędzi cyfrowych z korzystaniem z programu liczącego czas pracy. To pracodawca będzie zobowiązany zapewnić tego typu narzędzie, zatem odwrotnie niż w polskiej regulacji pracy zdalnej, w której to pracownik ma prowadzić ewidencje wykonanych czynności obejmującą czas pracy. Inspiracją dla tego przepisu był wyrok Trybunału Sprawiedliwości Unii Europejskiej z dnia 14 maja 2019 roku w sprawie Federación de Servicios de Comisiones Obreras (CCOO) przeciwko Deutsche Bank SAE (C-55/18, ECLI:EU:C:2019:402). Stwierdzono w nim, że:

w celu zapewnienia skuteczności (effet utile) praw przewidzianych w dyrektywie 2003/88 i prawa podstawowego zapisanego w art. 31 ust. 2 karty państwa członkowskie zobowiązane są do nałożenia na pracodawców obowiązku wdrożenia obiektywnego, niezawodnego i dostępnego systemu umożliwiającego pomiar dobowego czasu pracy świadczonej przez każdego pracownika (pkt 60),

a to zaś wchodzi w zakres:

spoczywającego na państwach członkowskich i pracodawcach ogólnego obowiązku wprowadzenia organizacji i środków koniecznych do zapewnienia ochrony bezpieczeństwa i zdrowia pracowników (pkt 62).

Ważnym aspektem wdrożenia tego mechanizmu jest konieczność zapewnienia pracownikowi prawa do prywatności i ochrony danych osobowych. Należy zauważyć, że jeśli pracownik korzysta w pracy z komputera i telefonu, to tego rodzaju oprogramowanie będzie musiało zostać zainstalowane na obu urządzeniach.

Artykuł 4 projektu Parlamentu Europejskiego regulujący środki wdrażania prawa do bycia offline wymaga nakazania przez państwa członkowskie uregulowania kwestii związanych z realizacją tego prawa w swoistych źródłach prawa pracy, przez określenie minimalnych wymagań co do ich treści. Rozwiązanie to jest pragmatyczne, pozwala na uwzględnienie specyfiki danego zakładu pracy. Jednocześnie konieczne jest uregulowanie sytuacji pracowników nieobjętych regulaminem lub układem. W tym zakresie celowe wydaje się nakazanie wydania przez pracodawcę stosownego obwieszczenia. W skazane akty powinny zawierać: praktyczne ustalenia dotyczące wyłączenia narzędzi cyfrowych, system pomiaru czasu pracy, oceny bezpieczeństwa i higieny pracy w odniesieniu do prawa do bycia offline, kryteria stosowania odstępstw (w sytuacji siły wyższej lub w innych nadzwyczajnych sytuacjach) i kryteria ustalania prawa do rekompensaty. Zgodnie z projektem konieczne jest również wdrożenie środków uświadamiających, w tym szkoleń, dotyczących realizacji prawa do bycia offline.

To, co zostało przedstawione, potwierdza, że prawo do bycia offline znajduje się na styku problematyki związanej z czasem pracy, a w szczególności z jego ograniczeniem w wymiarze dobowym, oraz zagadnieniami związanymi z bezpieczeństwem i higieną pracy. 
W rezolucji Parlamentu Europejskiego podkreślono, że korzystanie z prawa do bycia offline, polegające na nieangażowaniu się $\mathrm{w}$ zadania związane $\mathrm{z}$ pracą i nieuczestniczenie w działaniach i komunikacji elektronicznej poza czasem pracy, nie może powodować negatywnych konsekwencji dla pracowników ani ich wiktymizacji. Jednocześnie zaznaczono konieczność wdrożenia mechanizmów rozpatrywania skarg lub naruszeń prawa od bycia offline. W preambule projektu Parlamentu Europejskiego wskazano, że pracownikom korzystającym ze swoich praw należy zapewnić ochronę przed wszelkimi negatywnymi konsekwencjami, $w$ tym przed zwolnieniem i innymi działaniami odwetowymi. Jednocześnie to na pracodawcy winien spoczywać ciężar dowodu wykazania, że pracownik został zwolniony z innych przyczyn, jeśli ten uprawdopodobni, że zwolnienie lub inne negatywne konsekwencje nastąpiły z tych powodów.

Przedstawione postulaty znalazły odzwierciedlenie w art. 5 projektu Parlamentu Europejskiego, w którym przewidziano regulacje ochronne dla pracownika przed niekorzystnym traktowaniem. Państwa członkowskie na mocy tego przepisu miałyby zostać zobligowane do wprowadzenia regulacji obejmującej zakaz dyskryminacji, mniej korzystnego traktowania, zwalniania i stosowania innych niekorzystnych środków w stosunku do pracowników wykonujących prawo do bycia offline. Jednocześnie pracownicy, którzy złożyli skargę przeciwko pracodawcy bądź zainicjowali postępowanie w celu wyegzekwowania praw, mieliby być chronieni przez pracodawców. Wreszcie zaproponowano ułatwienia dowodowe dla pracowników.

Omawiane regulacje ochronne wykluczają stosowanie wobec pracownika powołującego się na korzystanie z prawa do bycia offline zarówno sankcji porządkowych, jak i rozwiązania z nim umowy o pracę za wypowiedzeniem i bez wypowiedzenia.

Należy zauważyć istotne podobieństwo projektowanych rozwiązań do występujących na gruncie dyrektyw równościowych (w zakresie ułatwień dowodowych i ochrony powołującego się na naruszenie), przy czym projekt Parlamentu Europejskiego nie przewiduje wprost odszkodowania jako sankcji za naruszenie przedmiotowej regulacji. Nie należy bowiem utożsamiać rekompensaty, o której mowa w art. 4, z sankcją za naruszenie proponowanej regulacji. W przypadku rekompensaty chodzi bowiem o sytuację usprawiedliwionego odstępstwa. Bartłomiej Kurcz uważa, że prawo wspólnotowe (obecnie unijne) nie może być uznane za lex imperfecta. Wskazuje on, że swoboda państw członkowskich przy implementacji może być w tym zakresie różna, gdyż przepisy unijne mogą same wyznaczać określone sankcje, zawierać jedynie ogólny obowiązek ich wprowadzenia, zawierać ich przykładową listę, bądź w ogóle na nie nie wskazywać (Kurcz 2004, s. 155-156).W omawianym przypadku mamy do czynienia z drugą sytuacją.

Do projektu Parlamentu Europejskiego odniosła się Europejska Konfederacja Związków Zawodowych (ang. European Trade Union Confederation, ETUC). W stanowisku z dnia 22-23 marca 2021 stwierdzono, że konieczne jest efektywne zapobieganie sytuacjom, w których pracodawcy wymagają dostępności pracowników po godzinach pracy lub ją promują (ETUC 2021). Podkreślono także konieczność powstrzymywania się przez współpracowników od kontaktu lub komunikowania się w tym czasie. Wskazano na konieczność informowania i uwrażliwiania w tej kwestii osób zatrudnionych 
w przedsiębiorstwach międzynarodowych, w których pracownicy wykonują swoje obowiązki w różnych strefach czasowych. Zauważono także konieczność podkreślenia, że czas, w którym pracownik jest dostępny dla pracodawcy, to czas pracy, co wymaga ustanowienia obiektywnego, niezawodnego i przejrzystego systemu umożliwiającego rejestrowanie czasu przepracowanego. Wskazano także na element nieuwzględniony w projekcie Parlamentu Europejskiego, to jest związek prawa do odłączenia z obciążeniem pracą i jego oceną.

\section{Wdrożenie pracy zdalnej do Kodeksu pracy a regulacja prawa do bycia offline}

Kodeks pracy, jak zostało wspomniane, nie zawiera regulacji dotyczącej prawa pracownika do bycia offline. Aktualnie prowadzone są prace legislacyjne, których celem jest wprowadzenie regulacji pracy zdalnej do Kodeksu pracy (projekt ustawy o zmianie ustawy - Kodeks pracy, ustawy o rehabilitacji zawodowej i społecznej oraz zatrudnianiu osób niepełnosprawnych oraz ustawy o promocji zatrudnienia i instytucjach rynku pracy z dnia 18 maja 2021 roku, numer w wykazie prac legislacyjnych Rady Ministrów: UD 210), w których także zabrakło propozycji unormowania tej kwestii. O ile z uwagi na to, że obecna regulacja pracy zdalnej ma charakter epizodyczny, a wobec zasadniczo dużego zainteresowania tą formą wykonywania pracy celowe wydaje się wprowadzenie jej do Kodeksu pracy - za tym rozwiązaniem optują Dariusz Makowski (2020, s. 10) i Leszek Mitrus (2020b, s. 4), a Ludwik Florek (2021, s. 2) uważa wręcz, że powinna się ona przyczynić do zwiększenia szans pewnych grup osób niepełnosprawnych na rynku pracy - o tyle jednoczesny brak propozycji w zakresie uregulowania prawa pracownika do bycia offline musi budzić pewne obawy, jak również zdziwienie. Wynikają one $\mathrm{z}$ tego, że problematyka ta jest obecnie istotnym elementem dyskusji w europejskim obszarze prawa pracy i należy wyrazić nadzieję, że polski ustawodawca nie pozostanie na nią głuchy i w sposób odpowiedzialny do niej podejdzie. Jeżeli omawiana rezolucja zaowocuje wydaniem dyrektywy, to oczywiście zaistnieje konieczność jej implementacji, jednakże dostrzeżona już potrzeba uregulowania omawianej kwestii może stanowić impuls do samodzielnego działania państw członkowskich i nic nie stoi na przeszkodzie, aby stosowna regulacja znalazła swoje odzwierciedlenie w Kodeksie pracy już teraz. Pomimo że aktualny projekt zmiany Kodeksu pracy nie nakłada takiego obowiązku, wydaje się, że nie ma przeszkód, aby taką regulację wprowadziły zainteresowane strony. Niewątpliwie ustalenia w kwestii sposobu realizacji prawa do bycia offline mogłyby zostać uszczegółowione w porozumieniu lub regulaminie dotyczącym zasad wykonywania pracy zdalnej w części dotyczącej zasad porozumiewania się pracodawcy i pracownika wykonującego pracę zdalną (art. $67^{20} \$ 6$ pkt 4 projektu). Dla urealnienia przysługującej pracownikowi ochrony, w razie uregulowania prawa do bycia offline, pracownik powinien otrzymać informację o przysługującym mu prawie w ramach informacji udzielanej mu na podstawie projektowanego art. $67^{21}$. Sama ocena planowanych rozwiązań w zakresie 
pracy zdalnej przekracza ramy niniejszego opracowania i nie zostanie w tym miejscu przeprowadzona.

\section{Podsumowanie}

Przejście na tryb pracy zdalnej w związku z pandemią COVID-19 stanowiło swoisty katalizator dla prac - w ramach Unii Europejskiej - nad rozwiązaniami dotyczącymi zagwarantowania pracownikom prawa do bycia offline. $Z$ jednej strony podkreślenia wymaga, że nie jest ono ideą powstałą nagle, ale rozwijającą się wraz z ekspansją nowych technologii i sposobów komunikacji w stosunkach pracy. Zdecydowanie można powiedzieć, że nadszedł już czas, kiedy brak wyodrębnienia tego prawa działa na niekorzyść pracowników. Jednocześnie trzeba zauważyć, że nie jest to prawo w pełni samodzielne i odrębne od tych, które w prawie pracy występują. Nie umniejsza to jednak jego znaczeniu, a potrzeba jego wyróżnienia nie może być kwestionowana. Wynika to $z$ ewolucji świata pracy i związanego z tym ryzyka, a także potrzeb po stronie zatrudnionych, które nie są w pełni odzwierciedlone w zastanych regulacjach. Treściowo wiąże się ono z prawem pracownika do odpoczynku oraz bezpiecznych i higienicznych warunków pracy.

Proponowany przez Parlament Europejski projekt dyrektywy mógłby wprowadzić w regulowanym zakresie minimalny poziom ochrony, co wynika ze specyfiki tego aktu Unii Europejskiej, przez wskazanie podstawowych warunków pracy niezbędnych do realizacji prawa do odłączenia. Akt ten, definiując pojęcie bycia offline, pozwala na precyzyjne określenie zakresu przedmiotowego tego prawa. Należy dodatkowo zauważyć, że dookreślenie warunków pracy w swoistych źródłach prawa pracy umożliwiłoby odpowiednie ich ukształtowanie w stosunku do potrzeb i kultury pracy danego zakładu pracy. Istotnym osłabieniem planowanej regulacji jest odległa i niepewna data wejścia jej w życie, w szczególności z uwagi na to, że zagrożenie praw pracowników ma miejsce już teraz i może przybierać na sile.

\section{Bibliografia}

Baran K.W., Książek D. (2020) [w:] K.W. Baran (red.), Tarcza antykryzysowa 1.0- 4.0, ustawa o dodatku solidarnościowym i inne regulacje, jako szczególne rozwiązania $w$ prawie pracy, prawie urzędniczym i prawie ubezpieczeń społecznych związane z COVID-19. Komentarz, Warszawa.

Barcz J. (2017) [w:] J. Barcz, M. Górka, A. Wyrozumska, Instytucje i prawo Unii Europejskiej, Warszawa.

Bradley K. (2017) Legislating in the European Union [w:] C. Barnard, S. Peers (red.), European Union Law, Oxford.

Florczak A. (2009) Ewolucja ochrony praw człowieka w systemie prawa wspólnotowego [w:] A. Florczak (red.), Ochrona praw podstawowych w Unii Europejskiej, Warszawa. 
Florek L. (2021) Prawne ramy pracy zdalnej, „Z Problematyki Prawa Pracy i Polityki Socjalnej”, t. 2. Gładoch M. (2020) Praca zdalna w praktyce. Zagadnienia prawne, Warszawa.

Gładoch M. (2021) Praca zdalna - szanse i zagrożenia, wystąpienie na Ogólnopolskiej Konferencji Naukowej pt. „Stosunki pracy w dobie pandemii”.

Góral Z. (2017) Podstawowe zasady indywidualnego prawa pracy [w:] K.W. Baran (red.), System prawa pracy, t. 1: Część ogólna, Warszawa.

Górka M. (2017) [w:] J. Barcz, M. Górka, A. Wyrozumska, Instytucje i prawo Unii Europejskiej, Warszawa.

Grzeszczak R. (2012) [w:] D. Kornobis-Romanowska, J. Łacny, A. Wróbel (red.), Traktat o funkcjonowaniu Unii Europejskiej. Komentarz, t. 3: (art. 223-358), Warszawa.

Hüpers B., Reese B. (2019) [w:] J. Meyer, S. Hölscheidt (red.) Charta der Grundrechte der Europäischen Union, Baden-Baden.

Jarass H. (2021) Charta der Grundrechte der Europäischen Union unter Einbeziehung der sonstigen Grundrechtsregelungen des Primärrechts und der EMRK : Kommentar, München.

Kiełbasa M. (2017) Prawa socjalne w Unii Europejskiej a granice swobód rynku wewnętrznego, Warszawa.

Kornobis-Romanowska D. (2016) Prawa podstawowe w orzecznictwie TSUE jako czynnik konstytucjonalizacji czy umiędzynarodowienia prawa UE? [w:] D. Kornobis-Romanowska (red.), Unia Europejska $w$ roli gwaranta i promotora praw podstawowych, Sopot.

Krzywoń A. (2017) Konstytucyjna ochrona pracy i praw pracowniczych, Warszawa.

Książek D. (2020) Wpływ nowych technologii na kształtowanie warunków pracy, „Monitor Prawa Pracy", nr 20 (dodatek).

Kurcz B. (2004) Dyrektywy Wspólnoty Europejskiej i ich implementacja do prawa krajowego, Warszawa.

Kurcz B. (2012) [w:] D. Kornobis-Romanowska, J. Łacny, A. Wróbel (red.), Traktat o funkcjonowaniu Unii Europejskiej. Komentarz, t. 3: (art. 223-358), Warszawa.

Makowski D. (2020) Kilka uwag o pracy zdalnej, „Praca i Zabezpieczenie Społeczne”, nr 10.

Mitrus L. (2013) Prawa społeczne w Karcie Praw Podstawowych Unii Europejskiej, „Państwo i Prawo", nr 7.

Mitrus L. (2020a) Praca zdalna de lege lata i de lege ferenda - zmiana miejsca wykonywania pracy czy nowa koncepcja stosunku pracy? Czesśc 1, „Praca i Zabezpieczenie Społeczne”, nr 10.

Mitrus L. (2020b) Praca zdalna de lege lata i de lege ferenda - zmiana miejsca wykonywania pracy czy nowa koncepcja stosunku pracy? Czesść 2, „Praca i Zabezpieczenie Społeczne”, nr 11.

Mitrus L. (2020c) [w:] A. Wróbel (red.), Karta praw podstawowych Unii Europejskiej. Komentarz, Warszawa.

Pisarczyk Ł., Boguska A. (2020) Sfera zatrudnienia w działaniach antykryzysowych. Wybrane zagadnienia, „Monitor Prawa Pracy”, nr 5.

Rycak M. (2020) Prawa i obowiazkki stron stosunku pracy w czasie pandemii COVID-19, „Studia z Zakresu Prawa Pracy i Polityki Społecznej”, t. 27, nr 4.

Secunda P.M. (2019) The Employee Right to Disconnect, „Notre Dame Journal of International \& Comparative Law”, Vol.9, Issue 1, https://scholarship.law.nd.edu/ndjicl/vol9/iss1/ (dostęp: 14 maja 2021). 
Sobczyk A., Buch D. (2016) [w:] A. Safjan, L. Bosek (red.), Konstytucja Rzeczypospolitej Polskiej. Komentarz, Warszawa.

Surdykowska B. (2019) Prawo „do odłączenia” - coraz większe wyzwanie we współczesnym świecie pracy, „Monitor Prawa Pracy”, nr 12.

Surdykowska B. (2020) Świeże spojrzenie TSUE na Kartę praw podstawowych Unii Europejskiej, „Praca i Zabezpieczenie Społeczne”, nr 2.

Wojnicka-Sycz E. (2013) Narzędzia ICT wspierające proces innowacyjny, „Zarządzanie i Finanse”, nr 4, cz. 1.

Wyrozumska A. (2017) [w:] J. Barcz, M. Górka, A. Wyrozumska, Instytucje i prawo Unii Europejskiej, Warszawa.

Zagrobelny J. (2020) [w:] W.K. Brzostowski, A. Giżejowska, M. Gładoch, K. Kopeć, P. Korus, A. Sobczyk, G. Sykała, J. Zagrobelny (red.), Regulacje COVID-19 w prawie pracy, Warszawa.

\section{Źródła internetowe}

BusinessEurope, SMEunited, CEEP, ETUC (2020) European Social Partners Autonomous Framework Agreement on Digitalisation, https://www.etuc.org/system/files/document/ file2020-06/Final\%2022\%2006\%2020_Agreement\%20on\%20Digitalisation\%202020.pdf (dostęp: 14 maja 2021).

EPRS (2020) The Right to Disconnect, https://www.europarl.europa.eu/RegData/etudes/ BRIE/2020/642847/EPRS_BRI(2020)642847_EN.pdf (dostęp: 14 maja 2021).

ETUC (2021) ETUC Position on the Right to Disconnect, https://www.etuc.org/en/document/ etuc-position-right-disconnect (dostęp: 14 maja 2021).

Eurofound (2020a) The Right to Disconnect in the 27 EU Member States, https://www.eurofound. europa.eu/sites/default/files/wpef20019.pdf (dostęp: 17 maja 2021).

Eurofound (2020b) COVID-19 Unleashed the Potential For Telework - How Are Workers Coping?, https://www.eurofound.europa.eu/nb/publications/blog/covid-19-unleashed-the-potential-for-telework-how-are-workers-coping (dostęp: 5 maja 2021).

GUS (2016) Społeczeństwo informacyjne w Polsce, https://stat.gov.pl/obszary-tematyczne/ nauka-i-technika-spoleczenstwo-informacyjne/spoleczenstwo-informacyjne/spoleczenstwo-informacyjne-w-polsce-wyniki-badan-statystycznych-z-lat-2012-2016,1,10.html (dostęp: 14 maja 2021).

\section{Orzecznictwo}

Wyrok Trybunału Sprawiedliwości Unii Europejskiej z dnia 6 listopada 2018 roku w sprawie Max-Planck-Gesellschaft zur Förderung der Wissenschaften eV przeciwko Tetsujiemu Shimizu, C-684/16, ECLI: EU:C:2018:874.

Wyrok Trybunału Sprawiedliwości Unii Europejskiej z dnia 6 listopada 2018 roku w sprawie Stadt Wuppertal przeciwko Marii Elisabeth Bauer oraz Volker Willmeroth, jako właściciel spółki TWI Technische Wartung und Instandsetzung Volker Willmeroth eK przeciwko Martinie Broßonn, C-569/16 i C-570/16, ECLI: EU:C:2018:871. 
Wyrok Trybunału Sprawiedliwości Unii Europejskiej z dnia 14 maja 2019 roku w sprawie Federación de Servicios de Comisiones Obreras (CCOO) przeciwko Deutsche Bank SAE, C-55/18, ECLI: EU:C:2019:402.

\section{Akty prawa krajowego}

Konstytucja Rzeczypospolitej Polskiej z dnia 2 kwietnia 1997 roku, Dz.U. 1997, nr 78, poz. 483 z dnia 16 lipca 1997 roku.

Projekt ustawy o zmianie ustawy - Kodeks pracy, ustawy o rehabilitacji zawodowej i społecznej oraz zatrudnianiu osób niepełnosprawnych oraz ustawy o promocji zatrudnienia i instytucjach rynku pracy z dnia 18 maja 2021 roku, numer w wykazie prac legislacyjnych Rady Ministrów: UD210.

Ustawa z dnia 26 czerwca 1974 roku - Kodeks pracy, Dz.U. 2020, poz. 1320 tekst jedn. ze zm.

Ustawa z dnia 18 lipca 2002 roku o świadczeniu usług drogą elektroniczną, Dz.U. 2020, poz. 344 tekst jedn.

Ustawa z dnia 2 marca 2020 roku o szczególnych rozwiązaniach związanych z zapobieganiem, przeciwdziałaniem i zwalczaniem COVID-19, innych chorób zakaźnych oraz wywołanych nimi sytuacji kryzysowych, Dz.U. 2020, poz. 1842 tekst jedn.

Ustawa z dnia 19 czerwca 2020 roku o dopłatach do oprocentowania kredytów bankowych udzielanych przedsiębiorcom dotkniętym skutkami COVID-19 oraz o uproszczonym postępowaniu o zatwierdzenie układu w związku z wystąpieniem COVID-19, Dz.U. 2021, poz. 1072 tekst jedn.

\section{Akty prawa międzynarodowego}

Dyrektywa 2003/88/WE Parlamentu Europejskiego i Rady z dnia 4 listopada 2003 roku dotycząca niektórych aspektów organizacji czasu pracy, Dz.Urz. UE L 2003, nr 299/9.

Karta praw podstawowych Unii Europejskiej, Dz.Urz. UE C 2012, nr 326/02.

Powszechna deklaracja praw człowieka z dnia 10 grudnia 1948 roku, Paryż [w:] A. Bieńczyk-Missala (red.), Międzynarodowa ochrona praw człowieka. Wybór dokumentów, Warszawa 2008.

Protokół (nr 30) w sprawie stosowania Karty praw podstawowych Unii Europejskiej do Polski i Zjednoczonego Królestwa (Dz.Urz. UE C 2010, nr 83/313).

Rezolucja Parlamentu Europejskiego z dnia 21 stycznia 2021 r. zawierająca zalecenia dla Komisji w sprawie prawa do bycia offline (2019/2181(INL)).

Traktat o funkcjonowaniu Unii Europejskiej, Dz.Urz. UE C 2012, nr 326/47.

Traktat o Unii Europejskiej, Dz.Urz. UE C 2012, nr 326/13. 